\title{
Linking Letters: Translating Ancient History into Medieval Romance
}

\author{
Alex Mueller* \\ University of Minnesota - Twin Cities
}

Abstract

This essay won the 2006 Literature Compass Graduate Essay Prize, Medieval Section.

In his prologue to the late fourteenth-century romance, the Destruction of Troy, John Clerk of Whalley negotiates between his roles as translator, historian and alliterative poet to introduce his account of the fall of Troy for medieval English readers. Professing to tell the true story of Britain's ancient ancestors, he invokes the fiction of translatio imperii, in which the power of empire passes from Troy to Rome to Britain. According to Clerk, his translation of Guido delle Colonne's Historia destructionis Troiae provides vernacular readers access to historical truth that had not previously been available to them. Clerk's assumption of Guido's history separates his romance from the historiographic tradition of the vastly influential Geoffrey of Monmouth, whose Historia regum Britannie celebrates Britain's Trojan ancestry and promises future glory to the Britons. Rather than venerate Troy as a font of imperial power, Guido condemns the martial policy of the Trojans that causes their defeat, characterizing Troy as a tainted origin of Western civilization. By comparing Clerk's text with another translation of Guido's Historia, John Lydgate's Troy Book, I argue that Clerk's translational method, which he calls a 'linking of letters', reflects a commitment to connecting a destructive past with an English present.

Over the last two decades, medieval romance has been increasingly read as historiography. ${ }^{1}$ Geoffrey of Monmouth's Historia regum Britannie has been central to this trend because it is simultaneously informed by the genres of romance and history. Through the secular use of translatio imperii, a prophetic model that promises future imperial glory for Britain, Geoffrey's text joins the romans d'antiquite in their exemplification of twelfth-century NormanAngevin political ideology, which justified its nobility by claiming Roman and Trojan ancestry. ${ }^{2}$ This Angevin propaganda is based on an optimistic rendering of translatio, a theory of the transfer of world power that originates in ancient Greek historiography and early biblical exegesis, in which the fall of Babylon leads to the birth and eventual destruction of future empires such as Persia and Macedonia. ${ }^{3}$ Early Jews and Christians interpreted the dream visions in Daniel II and VII as the succession of world-empires that would end with the greatest of them all, that is, Rome. ${ }^{4}$ By the ninth (c) 2007 The Author

Journal Compilation ( 2007 Blackwell Publishing Ltd 
century, translatio began to be conceived as political concept in papal historiography that authorized the Pope's transfer of the Roman Empire to the German Holy Roman Empire. The translatio of Western Christendom reached its climax in the thirteenth century, when Innocent III endowed Charlemagne with Roman imperium, an action that asserted the papacy's pivotal role in such translations of power. ${ }^{5}$ Geoffrey, however, circumvents these ecclesiastical claims in his Historia and locates the origin of translatio in the destruction of Troy, whose fall spawns both the birth of Rome and Britain. This secularization of the theory has fascinated scholars because it is discernable in a vast number of historical and literary works, including Middle English alliterative romance. Geoffrey's historiographic influence is such that Geraldine Heng has even claimed that by

giving Britain a regnal genealogy extending back to the glories of ancient Troy through Brutus... Geoffrey's Historia ... supplies a foundational mythology irresistible to insular monarchs and virtually ensures that the Historia, issuing the foundational myth of Britain, will furnish the conditional matrix for imagining England as well. (66)

The idea that the Historia's legitimizing influence provides a 'matrix' for the England of the imagination has been helpful in characterizing late medieval conceptions of historical and royal authority, but its singularity has obscured other strains of historiography which did not provide such optimistic and linear models. While Galfridian scholars acknowledge the importance of other historical theories such as the biblical AugustinianOrosian paradigm that locates an origin in the Fall, their enthusiastic emphasis and exclusive tendency to 'mine' Geoffrey's text creates a body of scholarship that ultimately treats the Galfridian history as one that exclusively represents late medieval British perspectives of imperialism and serves as the exemplar for fourteenth- and fifteenth-century romance. ${ }^{6}$ This uncomplicated model, while attractive in its simplicity, does not fully account for the complexities of medieval romance and Trojan historiography after the twelfth century. ${ }^{7}$ Many subsequent writers did not embrace the Galfridian transfer of power, including the thirteenth-century Sicilian judge, Guido delle Colonne, who wrote Historia destructionis Troiae, which relates a version of the fall of Troy that differs markedly from the epics of Homer or Virgil. Rather than celebrate the deeds of Achilles and Aeneas or any other 'glories of Troy', he demonizes them and focuses upon the human treason and turns of fate that lead to the destruction of the city and its people. In Guido's text, Troy survives as a dismembered and tainted origin of Western civilization.

The significance of Guido's Historia to medieval England is best reflected in its English vernacular translations: the Laud Troy Book (c.1400), John Lydgate's Troy Book (1420) and most importantly for this study, John Clerk of Whalley's Destruction of Troy (c.1390). ${ }^{8}$ Critics have almost universally shunned the Destruction, because of its soporific content, repetitive alliterative units, lack of originality, fidelity to its source and its length. However, its 14,045 lines, the most of the alliterative genre, seem like a short lyric in 
comparison to Lydgate's version, which is an expansion of Guido's history that reaches a colossal 30,000 lines. ${ }^{9}$

If we turn to the prologues of these two translators, we gain insight into their differing perspectives on the appropriate manner in which to treat their source texts. They both have to negotiate carefully between their roles of translator and poet: Clerk transforms Guido's Latin into alliterative formulae while Lydgate translates Guido's Latin into Chaucerian iambic pentameter. Both translators remain dedicated to the historiographic principle of providing Guido's history for English readers, but while Lydgate prefers to moralize the story and temper its pessimistic message with extensive digressions, Clerk presents the unsavoury truth about Britain's destructive ancestors, eliminating and adding only what he deems necessary to contextualize Guido's history for an English audience.

Clerk's most interesting divergence emerges when he turns to Guido's justification for recording the truthful history of the fall of Troy. Guido goes into great detail about how stories are passed on and recorded by 'faithful preservers of tradition' (fidelia conseruatricia premissorum) emphasizing the importance of 'truth' (ueritatem) and a 'faithful writing' (fideli scriptura) of the story of Troy (3). ${ }^{10}$ Clerk perpetuates this interest in faithful history by making several claims under the auspices of 'truth', beginning with the use of the word '[s]othe' in line 11, and then continuing with similar references throughout the prologue. For both Guido and Clerk, their adherence to historical veracity distinguishes their accounts from writers who have skewed the truth according to their own biases. Guido specifically condemns these mendacious recorders as 'poets' (poetice) who attempt to disguise the truth with 'fictions' (fictionibus) (3-4). Clerk, being a poet, qualifies this slightly by translating Guido's 'poets' to 'sum poyetis' (33), which allows him to maintain the emphasis on truth telling and deflect the damnation of all versifiers. This, seemingly minor, change calls our attention to the complicated project that Clerk has undertaken: translating a truthful history not only from Latin to English, but also from prose to poetry. ${ }^{11}$

We may wonder, at the outset, if a medieval reader would believe it possible for Clerk to express the truth of history through poetry. According to the modern understanding of Aristotle's Poetics, history is particular and contingent, whereas poetry is universal and philosophical. Such a distinction implies an irreconcilable difference, but Aristotle qualifies this opposition by claiming that epic poetry draws on history in its thematic formulations. ${ }^{12}$ Indeed, Nietzsche did not think that poets, especially Roman ones, could accurately represent history because of their inattention to particularities. In his discussion of translation in The Gay Science, he condemns the ancient Romans for recklessly appropriating Greek texts as their own. His invective is specifically directed at poet-translators, who

had no sympathy for the antiquarian inquisitiveness that precedes the historical sense; as poets, they had no time for all those very personal things and names 
and whatever might be considered the costume and mask of a city, coast, or a century. (Nietzsche 136-8)

Nietzsche's assessment could be accurately applied to Clerk's tendency to Anglicize the Latin text, substituting English words and occupations for ones he did not recognize in Guido's Latin. Based on his readings of the ancient epic poets, Guido would have agreed with Nietzsche and accepted Aristotle's opposition of poets and historians.

However, since the Poetics was virtually unknown throughout the Middle Ages, and only accessible to the Latin West through translations of a tenthcentury Arabic version and Averroës' commentaries, Aristotle's thoughts on poetry were primarily gleaned from his 'scientific' works. ${ }^{13}$ Guido likely gained his perspective on poetry from Aristotle's Metaphysics, which demeaned poetry as merely a human invention and set below the divinity found in philosophy. ${ }^{14}$ Even though both poetry and philosophy emerge from states of wonder and doubt, it is only philosophers who can transcend the ignorance of poetic fable and access truth. ${ }^{15}$ Therefore, the Aristotelian idea in the Poetics that poetry is philosophical would have seemed very un-Aristotelian to Guido.

Also at work here is the medieval distinction between poetic and theological truth. The gold standard for truth was upheld by theological texts, which were true both at the literal and allegorical levels - in other words, they maintained their veracity in all senses. At the other end of the spectrum, poetry, or what Dante calls 'favola', was literally false, despite any allegorical truth it may contain. ${ }^{16}$ Guido condemns poets for writing stories that are false in the literal sense since such a commitment to falsehood entails 'playing with' (alludendo) the truth and deluding audiences into thinking that they are reading the truth (1). The use of alludendo is especially disparaging, because it implies that poetry is a frivolous activity. His invective is primarily directed toward Homer, who allegedly 'changed the pure and simple truth of his story into clever paths, touching on many things which did not happen and transforming those which did happen' (4). ${ }^{17}$ The most significant transformation was Homer's depiction of pagan gods fighting against the Trojans as if they were mortals.

Guido's charge against poets here is reminiscent of Plato's Republic, in which Socrates urges the poets not tell stories of gods acting impiously and warring against one another as they do in Homer's Iliad since such accounts blaspheme the gods and corrupt their hearers $(378 \mathrm{~b}-381 \mathrm{e}) .{ }^{18}$ Socrates even addresses the subject of Troy, saying, 'if anyone composes a poem about ... the tale of Troy ... we must require him to say that these things are not the work of a god' (380a). Homer's portrayals of the gods are false since the gods are inherently good, but Socrates does not claim that poets are inherently mendacious. In fact, he pleads that they indeed possess the capability to tell the truth since their accounts can have a profound effect on their readers $(378 \mathrm{~b}-\mathrm{e})$. Guido, on the other hand, presents Socrates's worst case scenario: he explains that the necessary consequence of these 
Homeric inventions was that other famous poets, such as Ovid, 'followed his [Homer's] error carefully'. ${ }^{19}$ Here Guido cleverly equates the commitment to fidelity of 'preservers' with the diligence of poets, but unlike the conseruatricia who adhere to truth, poets remain faithful to 'error'.

As a poet then, how does Clerk maintain his intention both to translate the truth and to versify it through the alliterative long line? Rather than compare the conseuatricia with the poete, Clerk begins more generally and in the passive voice, which allows him to suspend any judgments about the writers of truths and falsehoods.

So[th]e stories ben stoken vp \& straught out of mynd
And swolowet into swym by swiftenes of yeres
ffor new pat ben now next at our hond
Breuyt into bokes for boldyng of hertes
On lusti to loke with lightnes of wille
Cheuyt throughe chaunce \& chaungyng of peopull
Sum tru for to traist triet in pe ende
Sum feynit O fere \& ay false vnder. $(11-18)$

The subjectivity of a poet or recorder is completely absent here - Clerk shifts the focus to the 'stories' themselves and how they have been 'swolowet' by the passing of time and ' $[\mathrm{b}]$ reuyt' into books. Rather than blame the false tales on poetic deception, Clerk explains that after the intervention of 'chaunce' and fickle human nature, 'sum' remain 'tru' and 'sum' become 'false'. His refusal to translate Guido's blanket condemnation of all poets reflects Clerk's willingness to work against his source in order to further his poetic project and make the case that 'sum' poets are capable of writing truthful history. Of the English translators of the Historia, Clerk best defies Nietzschean accusations of recklessness, submits to Socrates' mandate, and most explicitly argues that 'true' poets could also serve as historians. Lydgate also qualifies Guido's condemnation of poets by claiming that of the poets that rehearsed the history of Troy, 'somme han the trouthe spared' (259), but still unleashes an invective against those who have 'transformed [the truth] in her poysy' (262) that has no equal in Destruction.

Despite their emphasis on the poet/historian dichotomy, medium mattered less than method to these translators. Dares and Dictys emerge as the authorities, not because they wrote in prose, but because they obtained their accounts through experience. They claim to have witnessed the events and recorded their observations in the method of a diarist, thereby inscribing the truth in a way that neither Homer nor Virgil was capable of doing. To emphasize the importance of these eyewitnesses, Clerk distinguishes his alliterative version of the history through a reorganization of the textual chronology. Unlike Guido and Lydgate, who move directly into a condemnation of Homer and all poets, Clerk separates his discussion of Homer and 'sum' poets who fictionalize the truth from his introduction by pausing to address the accounts that carry the most weight and interest for his audience. Here he privileges the "writing of wees pat wist it in dede, / 
With sight', (23-4) a direct reference to the eyewitnesses Dares and Dictys, whom he will nominally authorize forty lines later. The language that Clerk uses to describe the unnamed Dares and Dictys originates in Guido's Latin, but his choice to invoke the truth-bearing characteristic of their accounts before identifying the truth-bearers bestows privilege on the experiential authority of history over poetic mendacity. This is a significant structural change when read against his source and Lydgate's prologue. Guido does not sanction their accounts until he discusses them later in the prologue after his anti-Homeric tirade (4), and Lydgate, while admitting the veracity of their account, treats their authority with unusual complacence. After berating the inheritors of Homer's epic history for their translation of lies, he simply notes that Dares and Dictys 'were present and seyen everydel' (313), and anticlimactically observes that 'as it fel they write trewe and wel' (314). By indicating that they wrote the truth 'as it fel', Lydgate either straightforwardly identifies their compositional method or effaces their human agency as historians and relegates their written authority to chance. Clerk resolves any such ambiguity in his text by signalling the importance of eyewitness history early in his prologue and thereby expressing his devotion to the truth of the matter.

If Clerk privileges eyewitness truth over literary medium, how then can we explain his use of an alliterative long line that would have necessarily complicated an accurate translation of the history? To answer this question, we should attend to the end of the stanza, where Clerk arrives at a curious conclusion that has perplexed readers. He claims that these eyewitnesses wrote:

of hom pat suet after

To ken all the crafte how pe case felle, By lokyng of letturs pat lefte were of olde. (24-6)

While Clerk is most directly referring to Dares and Dictys, who provided the account for the use of future generations, the reference to the 'lokyng of letturs pat lefte were of olde' is difficult to decipher. The language that Clerk uses here has intrigued scholars of alliterative poetry because there is a similar phrase in the prologue to Sir Gawain and the Green Knight that appears directly after a discussion of the fall of Troy and the Trojan heritage of Britain. The Gawain-poet claims that he will tell his story in a tongue,

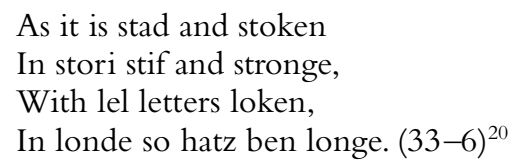

Like Clerk, the Gawain-poet makes reference to 'letters loken' that he will utilize to transmit a tale, but it is not clear what these 'locked letters' are. Malcolm Andrew and Ronald Waldron translate 'lel letters loken' as 'enshrined in true syllables', but concede that it could also mean 'linked with true letters'. The latter reading is especially attractive because it may 
either denote the precision of the metre or allude to the Anglo-Saxon tradition of the alliterative style. ${ }^{21}$

Rather than engage in the futile argument about what these lines say about the poetic medium of their Anglo-Saxon predecessors, I would like to suggest that these lines simply indicate an alliterative interest in the translation of history in the late fourteenth century. ${ }^{22}$ The 'lokyng' may then be read in a variety of ways that suit Clerk's project. Firstly, the 'lokyng' may be the 'securing' of the true account, which may have been performed by Dares and Dictys in the act of writing what they had witnessed. But since he does not specify them here as Lydgate does, Clerk may be referring to his own 'securing' of the truth through the act of translation, which makes the history available to a large audience. Secondly, the 'lokyng' may also mean 'locking' or 'linking', which may refer either to the combination of the accounts of Dares and Dictys by Guido, or to Clerk's own text that 'links' the Latin Trojan history to an English poetic tradition. This reading is corroborated by a direct reference to Dares and Dictys, who "wrote all pe werkes wroght at pat tyme / In letturs of pere langage as pai lerned hade' (58-9). The 'letturs' that they used to record their 'werkes' are most likely those same 'letters' that were 'linked/locked'. Read this way, the 'lokyng' is a combining that also 'locks' or ensures that the truth will be revealed. Finally, the 'lokyng' could signify a 'looking' that 'hom pat suet after' had to do in order to understand and pass on the truth about the fall of Troy. This reading alters the grammatical subject slightly, so that the 'lokyng' is performed not necessarily by any of the transmitters of the tradition such as Guido or Clerk, but could also include any reader of the texts that record the tale.

All of these readings that denote a 'securing', 'linking/locking' and 'looking', place an emphasis on an accurate, well preserved and rhetorically humble translation of the truth about Troy. It is tempting to read the 'lokyng' as a reference to a continuous or revived tradition of alliterative poetry in England, but we should curtail our desire to make too much of a 'classical' English tradition with little evidence to support it. Instead, I suggest that we read this 'lokyng of letturs' as a 'translating of words/accounts'. Understood this way, the specific use of the word 'lokyng' carries multiple meanings that encompass translation - after all, Clerk has to take special care both to link his words together to create effective alliterative units and to secure the truth about Troy through a translation that remains faithful to Guido. Whether or not the late fourteenth century witnessed a true 'revival' of this verse form or these texts constitute a continuous tradition of alliterative poetry, these poems actively engage in a poetic style of the past that, given the few surviving manuscripts, maintained a fragmentary existence and popularity among an audience that valued vernacular translations of the Latinate, Trojan historiographic tradition. ${ }^{23}$ Clerk then secures these accounts in a way that Plato would have certainly endorsed. As a poet, he translates the truth both linguistically and historically through the use of interlocking 
lines that serve a didactic purpose for future generations. Unlike some poets who link truth with falsity, Clerk locks this Latin 'eyewitness' account into an English alliterative word hoard that can be translated truthfully to future British generations. In so doing, Clerk promulgates Guido's version of the Troy story and rejects the Galfridian tradition that bases its ideologies upon poetic mendacities of Virgil and Homer. Clerk's 'locking' encourages the English reader to read his poem not as fanciful epic, but a work of sober history that privileges truth over entertainment.

After postponing and deflecting Guido's contempt for poets and establishing his authorial identity as a poet-translator, Clerk finally turns to the specifics of the Troy story. The separation between the stanza that ends with the 'lokyng of letturs' and the following stanza is clearly marked in the manuscript with a new rubric and large bold letters that begin the first line, 'Now of Troy ...' (27). It is only at this point that Clerk turns to the subject of his poem and joins Guido in a condemnation of false poets. Here we witness the tension between Latin prose and vernacular poetry - while Guido legitimizes his history through writing in Latin, Clerk plays down the authority of Latin and again reverts to generalities to avoid direct contradiction of Guido. Guido claims that his text ensures

that the true accounts of the reliable writers of this history may endure for all future time hereafter among western peoples, chiefly for the use of those who read Latin, so that they may know how to separate the true from the false among the things which were written of the said history in Latin books. ${ }^{24}$

Those 'Latin books' that fail to provide the whole truth are, of course, those of Homer, Ovid and Virgil. ${ }^{25}$

Guido's history is thus intended for a reading audience who values the truth-telling power of Latin prose. Lydgate, in trying to render Guido's Latin into English, cannot escape Guido's positivism about Latin and finally is forced to admit failure. Lydgate claims early on to translate both for his patron Henry V and for the 'lowe', but Lydgate's devotion to a vernacular telling of this history is tempered by his anxiety about his fidelity to the Latin text. He not only praises Guido's Latinity, but also prays that God help him remain faithful to the text $(372-84)$, a sentiment that continues throughout the prologue and first book, until he encounters a moment of crisis in Book II. At this point, his pen had begun to 'quake and tremble' (2.145) because he fears that his patron Henry ' $[\mathrm{m}] \mathrm{y}$ making rude schal beholde and rede' (2.148). He feels he cannot reproduce Guido's rhetorical colour, and is reduced to decide that since 'in ryme Ynglysch hath skarseté ... I ne can / Folwen Guido' (2.168-70) and 'I leve the wordis and folwe the sentence' (2.180).

In spite of Lydgate's desire to exalt the status of the English language, this translational disaster indicates that he feels that English cannot match the rhetorical complexity and sonority of the Latin language. This forces him to shift his fidelity from the Latin rhetoric to the historical ideas of Guido's text. He now calls on Clio, the muse of history, to help him in his historical 
project $(2.178-9)$, which effectively transforms his text from a translation to a moralistic tale that Derek Pearsall has called 'a homily first, an encyclopedia second, and an epic nowhere' (John Lydgate 129). By contrast, Clerk neither cowers nor relinquishes his emphasis on translation to provide the history of Troy for an English audience. While he acknowledges Guido's preference for Latin by relating that 'wise men haue written the wordes before / Left it in latyn for lernyng of vs' $(31-2)$, the rest of his references to language are more general and functional for the purposes of his narrative. To establish Guido's account as the authority, he does not refer to its Latin prose, but instead claims that of all the histories of Troy, Guido's is 'pe text euyn' (51). Clerk treats Dares and Dictys in a similar manner; since Guido never mentions the language they used to compose their diaries, Clerk characterizes their 'werkes' as written '[i]n letturs of pere langage as pai lerned hade' (58-9). Given his goal of 'lokyng' or translating letters for readers who neither know Latin nor possess memory of past historical events, the use of letters from 'their language' privileges the vernacular and inclusive narrative that he intends to provide for a new audience.

An examination of Clerk's prologue, its divergences from Guido's Historia, and its similarities and differences to Lydgate's Troy Book lead to four conclusions. Firstly, Clerk is a faithful translator who prefers compression and only embellishes when necessary. His fidelity to his source indicates that he makes no attempt to mollify Guido's pessimism about the consequences of the fall of Troy and therefore translates the warning against imperial designs for fourteenth-century English readers. Secondly, Clerk cleverly restructures his narrative and plays with shades of meaning in the words in order to further his alliterative poetic project. Thirdly, vernacular poetry can appropriately and accurately express Guido's Latinate 'eyewitness truth' about historical events. His manipulation of Guido's invective against poetry preserves the reputation of 'sum' poets who work to tell the whole truth and do not perpetuate the trifles of Homer, Ovid and Virgil. Fourthly and most importantly, as a quintessential poet-translator, Clerk amplifies the importance of translation, not only of language, but also of the message that the translation bears. 'By lokyng of letturs', Clerk employs a new language (English) and a new mode (alliterative poetry) in order to reach a new audience, who need to hear the dangers of imperial desires and war mongering. His fidelity and dedication to a truthful, anti-Homeric and anti-Galfridian account are attempts to define his poem as a serious work of translation and history that has the capability to question contemporary strains of imperial historiography.

\section{Short Biography}

After receiving a B.A. in English at the University of Colorado in 1996, Alex Mueller taught high school English for three years. During that time, he cultivated a personal interest in the history of the English language and 
its interactions with Classical and Medieval Latin, which inspired him to pursue a degree in Latin literature. He completed an M.A. in Classics at the University of Colorado in 2000 and then returned to high school teaching for another two years. In 2002, he left high school teaching to continue his graduate education at the University of Minnesota, where he is presently finishing his doctoral work in Medieval Studies. His dissertation, 'Translating Troy: Imperial Historiography and Middle English Alliterative Romance', is an investigation of late fourteenth-century English translations of Latin texts, particularly those about the fall of Troy, and the dissemination of British history through the genre of popular romance. His project focuses on how the critiques of war and imperialism in alliterative romance contribute to a distinctly vernacular understanding of English history and identity.

\footnotetext{
Notes

* Correspondence address: Department of English, University of Minnesota - Twin Cities, 207 Lind Hall, 207 Church Street SE, Minneapolis, MN 55455, USA. Email: muel0274@umn.edu.

${ }^{1}$ See Patterson, 'Historiography of Romance'; Negotiating the Past.

2 The romans d'antiquité are the Old French Roman de Thèbes, Roman d'Enéas and Roman de Troie. See Clogan 56-7; Folz. For translatio imperii, see Goez; Davis; Jaeger 263-4; Grundmann; Van den Baar; Angeli; Blumenfeld-Kosinski 157-8.

${ }^{3}$ See Mendels. Cf. Swain; Eddy 16-35; Flusser; Hartman and di Lella 31-3; Fuchs; Baumgartner; Winston.

${ }^{4}$ See de Boer 182-3.

${ }^{5}$ See Goez 137-88.

${ }^{6}$ Heng 2. While she qualifies the claim that Geoffrey's Historia is a source for the romance tradition, she contends that his text is a 'powerful, distinct moment when a species of magical narrative coalesced in an extraordinary pattern, out of a field of forces in culture and history, to create an exemplar for the romances that followed in the three hundred or more years to come, with an impact that ultimately traveled well beyond the Middle Ages itself'.

${ }^{7}$ It is important to distinguish between the simplicity of the Historia's imperial genealogical model and the complexity of Geoffrey's political purposes. While his specific political persuasions are difficult to identify, it is clear that his agenda is one that places Britain within the Roman line of imperial power. Except for those scholars who think that Geoffrey was not writing history at all most agree that the Historia is a legitimizing narrative of some kind; cf. Lloyd 528; Brooke; Clark 143. For a reading of its exaltation of non-monastic lifestyles, see Flint. For its concern with the Anglo-Norman elite, see Gerould 38; Kendrick 9. For its attention to 'cultural respectability' of the Welsh, see Barrow; Gillingham 19-39; Roberts 40; Knight 64-6.

${ }^{8}$ For a discussion of these translations, see Benson, History of Troy in Middle English Literature. For the date of Destruction, see John Clerk of Whalley iv. Future citations of Destruction refer to Matsumoto's edition. See also Benson, 'Chaucerian Allusion'; Sundwall. Benson suggests that the direct reference to Chaucer's Troilus and Criseyde in the lines 'Who-so wilnes to wit of paire wo fir, / Turne hym to Troilus and talke pere ynoghe' (8052-3), figures Destruction's terminus a quo to be $1385-7$.

9 All citations from Lydgate's Troy Book refer to Lydgate, Troy Book: Selections, ed. Robert R. Edwards (Kalamazoo, Michigan: Medieval Institute Publications, 1998).

${ }^{10}$ All citations from Guido's Historia refer to Guido de Columnis, Historia Destructionis Troiae, ed. Nathaniel Edward Griffin (Cambridge, MA: Mediaeval Academy of America, 1936).

${ }^{11}$ It is important to note that even though Guido claims to have followed the accounts of Dictys of Crete and Dares the Phrygian, Guido actually bases his translation on Benoit de Sainte-Maure's Le Roman de Troie. It is possible that Clerk knew Benoit's Roman, but it is more likely that he believed Guido translated directly from Dares and Dictys. See Dunger; Joly; Frazer 3-15.

${ }^{12}$ Hampton 88-92.
} 
13 Tigerstedt 7-8; Baumstark; Moraux; Maselli; Tkatsch; Kassel; Wolfson.

${ }^{14}$ Curtius 221.

15 Simpson 329.

16 Classical and Medieval Literary Criticism, eds. Preminger, Hardison Jr., and Kerrane, 406.

17 'eius ystorie puram et simplicem ueritatem in uersuta uestigia uariauit, fingens multa que non fuerunt et que fuerunt aliter transformando'.

18 All citations from Plato's Republic refer to Plato, The Republic, trans. Paul Shorey, The Loeb Classical Library (London: Heinemann, 1930).

19 'Cuius errorem ... curiosius insecuti'.

20 Poems of the Pearl Manuscript, ed. Andrew and Waldron.

21 Poems of the Pearl Manuscript, ed. Andrew and Waldron, 31-6n.

22 This metrical reading has been attractive to scholars of alliterative poetry such as Thorlac Turville-Petre and Christine Chism because it calls attention to the Middle English alliterative long line that is both aesthetically striking and encourages the reader to make aural and interpretive connections between individual words in each line. Hence, the reader must 'link' the 'letters' of the line in order to appreciate their consonance and ponder the significance of their juxtaposition. The use of this poetic form has traditionally been attributed to what has been called the Alliterative Revival, since the alliterative metre and vocabulary are deliberate archaisms, which has led Turville-Petre and Chism to speculate that the emergence of these poems may be evidence of an attempt to create a 'classical' genre of English poetry that looks back to earlier Anglo-Saxon poetry. See Chism 16-20; Turville-Petre. However, such an understanding of the phenomenon of alliterative poetry in the late fourteenth century has not been uniformly embraced by scholars. Derek Pearsall advises against reading these obscure references to 'linked letters' as an indication of the existence of either a continuous line or revival of alliterative poetry in the later Middle Ages since there is little evidence to support it. Rather, they may simply be conventional expressions that authorize old tales expressed through any medium and may not refer to their metre at all. Pearsall similarly rejects the connection between the similarity between the lines in SGGK and Destruction by claiming that Clerk's line is simply 'imitated' from Guido's prologue. See Pearsall, 'Alliterative Revival' 43.

23 Pearsall, 'Origins of the Alliterative Revival'.

24 'ut fidelium ipsius ystorie uera scribentium scripta apud occidentales omni tempore futuro uigeant successiue, in vtilitatem eorum precipue qui gramaticam legunt, ut separare sciant uerum a falso de hiis que de dicta ystoria in libris gramaticalibus sunt descripta'.

25 Thirteenth- and fourteenth-century readers would have most likely only known Homer from a rudimentary Latin translation. See Benson, History of Troy 3.

${ }^{26}$ Pearsall, John Lydgate 129.

\section{Works Cited}

Andrew, Malcolm and Ronald Waldron, eds. The Poems of the Pearl Manuscript: Pearl, Cleanness, Patience, Sir Gawain and the Green Knight. Exeter: U of Exeter P, 2002.

Angeli, Giovanna. L'Eneas e I primi romanzi volgari. Milan: Riccardo Ricciardi, 1971.

Barrow, G. W. S. 'Wales and Scotland in the Middle Ages'. Welsh Historical Review 10 (1980-1): 305.

Baumgartner, W. 'Zu den vier Reichen von Dan 2'. Theologische Zeitschrift 1 (1945): 17-22.

Baumstark, Anton. Aristoteles bei den Syrern vom V.-VIII. Jahrhundert. Leipzig, 1900.

Benson, C. D. 'A Chaucerian Allusion and the Date of the Alliterative Destruction of Troy'. Notes \& Queries 219 (1974): 206-7.

- The History of Troy in Middle English Literature: Guido delle Colonne's Historia destructionis Troiae in Medieval England. Woodbridge, Suffolk: D. S. Brewer, 1980.

Blumenfeld-Kosinski, Renate. 'Old French Narrative Genres: Towards the Definition of the Roman Antique'. Romance Philology 34 (1980): 143-59.

de Boer, S. 'Rome, the "Translatio Imperii" and the Early-Christian Interpretation of Daniel II and VII'. Rivista di storia e letteratura religiosa 21 (1985): 181-218.

Brooke, Christopher. 'Geoffrey of Monmouth as a Historian'. Church and Government in the Middle Ages. Eds. C. Brooke, D. E. Luscombe, G. H. Martin, and Dorothy Owen. Cambridge: Cambridge UP, 1976. 77-91.

(C) 2007 The Author

Literature Compass 4/4 (2007): 1017-1029, 10.1111/j.1741-4113.2007.00473.x

Journal Compilation @ 2007 Blackwell Publishing Ltd 


\section{Linking Letters}

Chism, Christine. Alliterative Revivals. University Park, PA: U of Pennsylvania P, 2002.

Clark, John. 'Trinovantum - the Evolution of a Legend'. Journal of Medieval History 7 (1981): 135-51.

Clogan, Paul M. 'New Directions in Twelfth-Century Courtly Narrative: Le Roman de Thèbes'. Mediaevistik 3 (1990): 55-70.

Curtius, Ernst Robert. European Literature and the Latin Middle Ages. Trans. Willard R. Trask. New York: Pantheon Books, 1953.

Davis, Charles T. Dante and the Idea of Rome. Oxford: Clarendon Press, 1957.

Dunger, Hermann. Die Sage vom troyanischen Kriege in den Bearbeitungen des Mittelalters und ihre antiken Quellen. Leipzig, 1869.

Eddy, S. K. The King is Dead. Lincoln: U of Nebraska P, 1961.

Flint, Valerie I. J. 'The Historia Regum Britanniae of Geoffrey of Monmouth: Parody and its Purpose. A Suggestion'. Speculum 54 (1979): 447-68.

Flusser, D. 'The Four Empires in the Fourth Sibyl and in the Book of Daniel'. Israel Oriental Studies 2 (1972): 148-75.

Folz, Robert. The Concept of Empire in Western Europe. Trans. S. A. Ogilvie. London: Edward Arnold, 1969.

Frazer, R. M. The Trojan War. Bloomington: Indiana UP, 1966.

Fuchs, H. 'ZurVerherrlichung Roms und der Römer in dem Gedichte des Rutilius Namatianus'. Basler Zeitschrift für Geschichte und Altertumskunde 42 (1943): 49-51.

Gerould, G. H. 'King Arthur and Politics'. Speculum 2 (1927): 33-51.

Gillingham, John. The English in the Twelfth Century: Imperialism, National Identity, and Political Values. Woodbridge, Suffolk: Boydell and Brewer, 2000.

Goez, Werner. Translatio Imperii: Ein Beitrag xtlr Gedichte des Geschichtsdenkens und der politischen Theorien im Mittelalter und in der frühen Neuzeit.Tübingen: Mohr, 1958.

Grundmann, H. 'Sacerdotium, Regnum, Studium'. Archiv für Kulturgeschichte 34 (1952): 5-21.

Guido de Columnis. Historia Destructionis Troiae. Ed. Nathaniel Edward Griffin. Cambridge, MA: Mediaeval Academy of America, 1936.

Hampton, Timothy. Writing from History: The Rhetoric of Exemplarity in Renaissance Literature. Ithaca: Cornell UP, 1990.

Hartman, L. G. and A. A. di Lella. The Book of Daniel. New York: Doubleday, 1978.

Heng, Geraldine. Empire of Magic: Medieval Romance and the Politics of Cultural Fantasy. New York: Columbia UP, 2003.

Jaeger, C. Stephen. The Origins of Courtliness. Philadelphia: U of Pennsylvania P, 1985.

John Clerk of Whalley. The Destruction of Troy: A Diplomatic and Color Facsimile Edition, Hunterian MS V.2.8 in Glasgow University Library. Ed. Hiroyuki Matsumoto. Ann Arbor: U of Michigan $\mathrm{P}, 2002$.

Joly, Aristide. Benoît de Sainte-More et le Roman de Troie ou les Métamorphoses d'Homére et L'Épopée Gréco-Latine au Moyen Age. Paris: F. Vieweg, 1870-1.

Kassel, Rudolf. Aristotelis de Arte Poetica Liber. Oxford: Clarendon Press, 1965.

Kendrick, T. D. British Antiquity. London: Methuen, 1950.

Knight, Stephen. Arthurian Literature and Society. New York: St. Martin’s Press, 1983.

Lloyd, J. E. A History of Wales 2. London: Longmans, Green \& Company, 1912.

Lydgate, John. Troy Book: Selections. Ed. Robert R. Edwards. Kalamazoo, MI: Medieval Institute Publications, 1998.

Maselli,Vito. 'Tradizione e cataloghi delle opere aristoteliche'. Rivista italiana di filologia e istruzione classica 34 (1956): 337-63.

Mendels, Daniel. 'The Five Empires: A Note on a Propagandistic Topos'. American Journal of Philology 102 (1981): 330-7.

Moraux, Paul. Les listes anciennes des ouvrages d'Aristote. Louvain: Éditions Universitaires de Louvain, 1951.

Nietzsche, Friedrich. The Gay Science. Trans. Walter Kaufmann. New York: Vintage, 1974.

Patterson, Lee. 'The Historiography of Romance and the Alliterative Morte Arthure'. Journal of Medieval and Renaissance Studies 13.1 (1983): 1-32.

- Negotiating the Past: The Historical Understanding of Medieval Literature. Madison: U of Wisconsin P, 1987.

Pearsall, Derek. 'The Alliterative Revival: Origins and Social Backgrounds'. Middle English Alliterative Poetry and its Literary Background. Ed. David Lawton. Cambridge: D. S. Brewer, 1982. 34-53. 
John Lydgate. Medieval Authors: Poets of the Later Middle Ages. London: Routledge and Kegan Paul; Charlottesville: UP of Virginia, 1970.

— . 'The Origins of the Alliterative Revival'. The Alliterative Tradition in the Fourteenth Century. Eds. Bernard S. Levy and Paul E. Szarmach. Kent, OH: Kent State UP, 1981.1-24.

Plato. The Republic. Trans. Paul Shorey. The Loeb Classical Library. London: Heinemann, 1930.

Preminger, Alex, O. B. Hardison, Jr., and Kevin Kerrane, eds. Classical and Medieval Literary Criticism: Translations and Interpretations. New York: F. Ungar, 1974.

Roberts, Brynley F. 'Geoffrey of Monmouth and the Welsh Historical Tradition'. Nottingham Medieval Studies 20 (1976): 29-40.

Simpson, James. 'Poetry as Knowledge: Dante's Paradiso XIII'. Forum for Modern Language Studies 25 (1989): 329-43

Sundwall, McKay. 'The Destruction of Troy, Chaucer's Troilus and Criseyde, and Lydgate's Troy Book'. Review of English Studies 26 (1975): 313-17.

Swain, J. W. 'The Theory of the Four Monarchies Opposition History under the Roman Empire'. Classical Philology 35 (1940): 1-21.

Tigerstedt, E. N. 'Observations on the Reception of the Aristotelian Poetics in the Latin West'. Studies in the Renaissance 15 (1968): 7-24.

Tkatsch, Jaroslaus. Die arabische Übersetzung der Poetik des Aristoteles, I-II. Vienna: Hölder-Pichler-Tempsky, 1928-32.

Turville-Petre, Thorlac. The Alliterative Revival. Cambridge: D. S. Brewer, 1977.

Van den Baar, H. Die kirchliche Lehre der Translatio Imperii Romani: bis zur Mitte des 13. Jahrhunderts. Analecta Gregoriana 78. Rome:Apud Aedes Universitatis Gregorianae, 1956.

Winston, D. 'The Iranian Component in the Bible, Apocrypha and Qumran'. History of Religions 5 (1966): 189-92.

Wolfson, Harry A. 'Revised Plan for the Publication of a Corpus Commentariorum Averrois in Aristotelem'. Speculum 38 (1963): 88-104. 